\title{
HUBUNGAN PENYAKIT GONDOK DENGAN KADAR YODIUM DALAM URIN MURID MADRASAH IBTIDAIYAH NEGERI (MIN) KORONG GADANG KECAMATAN KURANJI KOTA PADANG
}

\author{
Yustini Alioes \\ Staf Bagian Biokimia Fakultas Kedokteran Universitas Andalas \\ E-mail : yustinialioes@yahoo.com
}

Abstrak

Yodium adalah komponen esensial dalam asupan makanan manusia, yang merupakan bagian dari hormone tiroid yaitu tiroksin $\left(\mathrm{T}_{4}\right)$ and triiodotironin $\left(\mathrm{T}_{3}\right)$. Hormon tersebut dibutuhkan untuk menjaga metabolism basal, metabolism sel, dan kesatuan jaringan tubuh. Hormone tiroid diperlukan dalam perkembangan system sarat janin dan bayi. Kekurangan asupan yodium dapat menyebabkan penyakit gondok, yaitu pembesaran kelenjar tiroid. Gondok endemic merupakan hasil dari peningkatan kerja kelenjar tiroid oleh Thyroid Stimulating Hormone (TSH) dalam memaksimalkan penggunaan yodium yang tersedia, hal ini merupakan penyesuaian terhadap kekurangan yodium.

Tujuan penelitian ini adalah untuk mengetahui hubungan penyakit gondok dengan kadar yodium dalam urin murid Madrasah Ibtidaiyah Negeri Korong Gadang Kecamatan Kuranji Kota Padang.

Telah dilakukan penelitian pada 130 murid kelas II, III, IV, V dan VI di Madrasah Ibtidaiyah Negeri (MIN) Korong Gadang Kecamatan Kuranji Kota Padang. Data tentang prestasi belajar didaptkan dari hasil ujian semester. Pertumbuhan fisik ditentukan berdasarkan berat badan dan tinggi badan.

Selama penelitian ini didapatkan 80 anak $(61,5 \%)$ menderita penyakit gondok. Tidak didapatkan hubungan yang bermakna antara penyakit gondok dan kadar yodium dalam urin $(\mathrm{p}>0,05)$. Penelitian ini juga menemukan tidak terdapat hubungan antara penyakit gondok dan pertumbuhan fisik $(\mathrm{p}>0,05)$.

Kata Kunci : Iodium, urin, hipertiroid

\section{Abstract}

Iodine is an essential component of human diet, which part of thyroid hormones thyroxine $\left(\mathrm{T}_{4}\right)$ and triiodothyronine $\left(\mathrm{T}_{3}\right)$. These hormones are involved in the maintenance of metabolic rate, cellular metabolism and integrity of connective tissue. Thyroid hormones are necessary for the development of nervous system in the fetus and infant. Lack of dietary iodine is cause of goiter, an enlargement of the thyroid stimulating hormone (TSH) to maximize the utilization of available iodine and thus respresents maladaption to iodine deficiency.

The aim of this study was to investigate the relation between goiter with academic performance and urinary excretion iodine of children in Madrasah Ibtidaiyah Negeri (MIN) in Korong Gadang Kuranji District, Padang City. 
A cross sectional study has been done in 130 students of the second, third, fourth, fifth, and sixth degree of Madrasah Ibtidaiyah Negeri (MIN) Korong Gadang Kecamatan Kuranji Padang City. Data of academic performance was taken from the result of study in a semester. Physical growth was determined based on weight and height.

During the research, there were 80 children $(65,1 \%)$ who suffered from goitre. The correlation between goitre and academic performance are unsignificant $(p>0,05)$. This study was also found that there was no correlation between goitre and physical growth $(\mathrm{p}>0,05)$.

Key Word : Iodine, urine, hyperthyroidism 


\section{Pendahuluan}

Berhasilnya pembangunan Sumber Daya Manusia (SDM) suatu Negara dapat diketahui berdasarkan penilaian yang dilakukan oleh United Nations Development Program (LINDP) dengan indikator Human Development Index (HDI). HDI merupakan indikator peringkat kualitas SDM yang menggambarkan derajat kesehatan, gizi, pendidikan, dan ekonomi suatu negara pada kurun waktu tertentu. Pada tahun 2000 Indonesia berada pada urutan 109 dari 174 negara di dunia. ${ }^{(1)}$

Kualitas Sumber Daya Manusia (SDM) merupakan faktor utama yang di perlukan untuk melaksanakan pembangunan nasional. Untuk mencapai Sumber Daya Manusia (SDM) berkualitas, faktor gizi memegang peranan penting. Gizi yang baik dan menghasilkan Sumber Daya Manusia (SDM) yang berkualitas, sehat, cerdas, dan memiliki fisik yang tangguh serta produktif. $^{(2)}$ Gizi yang kurang akan menyebabkan kegagalan pertumbuhan fisik dan perkembangan kecerdasan, menurunkan produktifitas kerja dan menurunkan daya tahan tubuh yang berakibat pada meningkatnya angka kesakitan dan kematian. ${ }^{(3)}$

Perbaikan gizi diperlukan pada seluruh siklus kehidupan. Mulai sejak masa kehamilan, bayi, dan anak balita, prasekolah, anak SD, dan MI (Madrasah Ibtidayah), remaja, dewasa sampai usia lanjut. SD dan MI perlu diperhatikan dengan baik, karena disamping jumlahnya banyak yaitu sekitar 30\% dari jumlah penduduk, program gizi pada kelompok ini berdampak luas tidak saja pada aspek kesehatan, gizi, dan pendidikan masa kini tapi juga secara langsung mempengaruhi kualitas SDM dimasa datang. Masalah gizi yang sering ditemukan dan berdampak pada prestasi belajar dan pertumbuhan fisik anak SD dan MI diantaranya adalah kurang energi protein, anemia, gizi besi, Gangguan Akibat Kekurangan Yodium (GAKY). ${ }^{(2)}$

GAKY adalah serangkaian efek defisiensi yodium atau kekurangan yodium saat ini diperkirakan 1,6 milyar penduduk dunia mempunyai resiko kekurangan yodium dan 300 juta penduduk menderita gangguan mental akibat kekurangan yodium. Kira-kira 30.000 bayi lahir mati setiap tahun dan lebih dari 120.000 bayi kretin yakni retradasi mental, tubuh pendek, bisu, tuli atau lumpuh. ${ }^{(4)}$

Gangguan akibat kekurangan yodium di Indonesia merupakan salah satu masalah kesehatan masyarakat yang serius mengingat dampaknya sangat besar terhadap kelangsungan hidup dan kualitas SDM. Selain berupa pembesaran kelenjar gondok dan hipotiroid, kekurangan yodium jika terjadi pada ibu hamil mempunyai resiko terhadap terjadinya abortus, lahir mati, sampai cacat bawaan. Pada bayi yang lahir berupa gangguan perkembangan syaraf, mental dan fisik yang disebut kretin. $^{(5)}$ Kekurangan yodium pada orang dewasa menyebabkan pembesaran kelenjar gondok, hipotiroidi dan gangguan mental. Pada tingkat yang berat kekurangan yodium dapat menyebabkan cacat fisik dan mental, seperti bisu, tuli, mata juling, gangguan saraf motorik, pertumbuhan terganggu, badan lemah kecerdasan terganggu, dan retardasi mental. ${ }^{(6)}$ Semua gangguan ini dapat berakibat pada rendahnya prestasi belajar anak usia sekolah, rendahnya produktifitas kerja pada orang dewasa serta timbulnya berbagai masalah sosial ekonomi masyarakat yang dapat menghambat pembangunan. Dari sejumlah 20 juta penduduk Indonesia yang menderita gondok diperkirakan dapat kehilangan 140 juta angka kecerdasan (IQ point). ${ }^{(5)}$ Penderita gondok akan 
mengalami deficit IQ point sebesar 5 point dibawah normal. ${ }^{(7)}$

Hasil penelitian pada anak sekolah yang tinggal didaerah kekurangan yodium menunjukkan prestasi belajar dan IQ yang kurang jika dibandingkan dengan kelompok umur yang sama yang berasal dari daerah yang berkecukupan yodium. ${ }^{(4)}$ Rendahnya IQ biasanya identik dangan rendahnya tingkat kecerdasan seseorang. Turunnya tingkat kecerdasan pada generasi muda berarti hilangnya sebagian besar potensi cerdik pandai, ahli pikir, dan pemimpin-pemimpin yang diperlukan untuk kemajuan negara. Jadi jika keadaan ini tidak memperoleh perhatian yang memadai, maka dapat diramalkan kualitas sumber daya manusia Indonesia pada masa mendatang akan menurun. ${ }^{(8)}$

Dalam survei epidemiologi GAKY dapat digunakan dua teknik deteksi, yaitu memeriksa seluruh penduduk dan memeriksa satu kelompok terbatas. Memeriksa seluruh penduduk diperoleh angka pasti, menemukan gondok dengan berbagai variasi besar, kasus kretin endemik yang biasanya tidak diperoleh pada survei terbatas, tetapi cara mengorganisasinya lebih sulit, butuh waktu, tenaga dan dana banyak. Dengan memeriksa satu kelompok terbatas, cepat diperoleh kesan pada populasi tertentu, tapi jelas akan sulit menjumpai komplikasi yang sering menyertai defisiensi yodium berat, yaitu kretin endemik dan berbagai kelainan lainnya. Juga gondok yang besar tidak akan dijumpai pada anak sekolah, oleh sebab itu dianjurkan mulai dengan survei anak sekolah terlebih dahulu dan jika didapatkan angka melebihi 10\% maka dapat diteruskan dengan survey pada masyarakat seluruhnya. ${ }^{(9)}$

Indonesia termasuk Negara yang belum berhasil dalam penanggulangan GAKY, keadaan ini tampak dari hasil pemetaan GAKY Nasional tahun 2003 dengan meningkatnya prevalensi GAKY pada murid Sekolah Dasar dari $8,5 \%$ menjadi $10,8 \%$ dan dibeberapa propinsi terlihat daerah-daerah endemik sedang berat yang baru. Masalah Gangguan Akibat Kekurangan Yodium (GAKY) tersebar hampir diseluruh wilayah Indonesia termasuk Propinsi Sumatera Barat dengan prevalensi gondok pada anak sekolah 2003 adalah 9,8\% (endemik sedang), dimana sebagian besar penduduk bermukim didaerah pegunungan, tetapi keadaan itu tidak selalu benar, seperti yang dilaporkan oleh Thaha AR (2001) di Kepulauan Maluku, didapat prevalensi yang tinggi atau $>30 \%$ di beberapa gugus pulau di Propinsi Maluku. Hal yang sama juga terjadi di Hongkong seperti dilaporkan oleh Kung dkk (1996) yaitu rendahnya kadar yodium Laut Cina Selatan. Keadaan yang sama juga terjadi di beberapa kabupaten/kota di Propinsi Sumatera Barat yang termasuk kota-kota pantai, seperti Padang dan Padang Pariaman dengan prevalensi GAKY pada tahun 1998 sebesat $8,5 \%$ dan $15,2 \%$ mengalami peningkatan sebesar $21,5 \%$ dan $15,7 \%$ pada tahun $2003 .^{(10)}$

Survei pemetaan GAKY Kota Padang yang dilaksanakn oleh BAPPEDA dan Dinas Kesehatan Kota Padang bekerjasama dengan Fakultas Kedokteran Unand mendapatkan dari 33 SD di 11 kecamatan di Kota Padang ternyata $26,3 \%$ diantaranya telah mengalami pembesaran kelenjar gondok. Dari hasil survey tersebut salah satu dari tiga daerah endemik berat GAKY adalah Kecamatan Kuranji dengan TGR $32,1 \%{ }^{(10)}$

WHO, UNICEF, dan ICCIDD (International Council for Control of Iodine deficiency Disorders) tahun 2001 sepakat indikator untuk mengukur kemajuan kecukupan asupan 
yodium ada dua yaitu proses yodisasi garam dan impact, Kadar yodium dalam garam merupakan indikator keberhasilan proses yodisasi gatam, dan indikator untuk impact adalah IJEI (lrinary Excretion of lodine). UEI paling banyak dipakai sebagai marker biokimia untuk defisiensi yodium dengan beberapa alasan. Lebih dari $90 \%$ yodium dalam tubuh akan diekskresiksn lewat urin. ${ }^{(11)}$

Data dari Australia memperlihatkan terjadinya penurunan UEI. Nilai UEI penduduk Australia tahun $1992>20 \mu \mathrm{g} / \mathrm{L}$ tetapi tahun 20A3-2004 nilai UEI anak sekolah $100 \mu \mathrm{g} / \mathrm{L}$. Ini menunjukkan bahwa penambahan yodium dalam makanan sehari-hari terutama di daerah yang telah diketahui mempunyai masalah tetap diperlukan sepanjang masa. Pada tahun 2003 telah dilakukan Survei Evaluasi Intensifikasi Program GAKY yang mencakup 28 propinsi. Propinsi Sumatera Barat nilai UEI $279 \mu \mathrm{g} / \mathrm{L}$. ${ }^{(12)}$

Berdasarkan kenyataan ini, peneliti ingin melakukan penelitian tentang hubungan penyakit gondok dengan kadar yodium dalam urin pada anak Madrasah Ibtidaiyah Negeri (MIN) Korong Gadang Kecamatan Kuranji Kota Padang.

\section{METODE PENELITIAN \\ Desain Penelitian}

Jenis penelitian yang digunakan adalah penelitian deskriptif analitik dengan desain cross sectional study, dimana pengukuran variabel-variabelnya dilakukan hanya satu kali pada satu saat.

\section{Tempat dan Waktu Penelitian}

Penelitian ini dilaksanakan di Madrasah Ibtidaiyah Negeri Korong Gadang Kecamatan Kuranji Kota Padang. Penelitian dilaksanakan pada bulan Maret-Agustus 2008.

\section{Populasi}

Populasi penelitian ini adalah seluruh anak Madrasah Ibtidaiyah Negeri Korong Gadang Kecamatan Kuranji Padang kelas II sampai IV yang berjumlah 189 anak.

\section{Kriteria inklusi}

- Murid kelas II sampai VI yang menderita gondok.

- Bertempat tinggal di kecamatan Kuranji Padang.

- Bersedia ikut dalam penelitian dan mendapat izin tertulis dari orang tua untuk mengikuti Penelitian.

\section{Kriteria eksklusi}

- Mendapat pengobatan antitiroid dan hormonal sebelumnya.

- Tidak berada di tempat sewaktu melakukan penelitian.

- Tidak bersedia diwawancarai.

\section{Yariabel Penelitian dan Definisi}

Operasional

Variabel Penelitian

- Variabel indpenden: Penyakit Gondok.

- Variabel dependen: Kadar Yodium dalam Urin.

\section{Definisi Operasional}

a. Kadar yodium dalam urin yang di periksa dengan menggunakan metode spektrofotometer untuk mengetahui kadar yodium dalam urin.

Alat Ukur : Spektrofotometer Test.

Cara: Spekterofotometer Test.

Hasil : a. Ringan dan Sedang $\mathrm{UEI}<20-99 \mu \mathrm{g} / \mathrm{L}$

b. Adekuat UEI 100$199 \mu \mathrm{g} / \mathrm{L}$ 
c. Lebih dari Adekuat UEI $200-299 \mu \mathrm{g} / \mathrm{L}$

d. Kelebihan UEI > 300 $\mu \mathrm{g} / \mathrm{L}$

Skala : Ordinal.

b. Gangguan Akibat Kekurangan Yodium (GAKY) adalah sekumpulan gejala yang timbul karena tubuh seseorang kekurangan unsur yodium secara terus menerus dalam jangka waktu yang cukup lama. Salah satunya dapat mengakibatkan pembesaran kelenjar gondok.

Kejadian GAKY adalah ditemukannya penderita dengan pembesaran kelenjar tiroid. ${ }^{(9)}$ :

Alat Ukur : Jari Tangan.

Cara : Palpasi (Perabaan Kelenjar Tiroid).

Hasil : a. Tidak ada Pembesaran. b. Ada Pembesaran. Skala : Nominal.

\section{Grade Uraian}

\begin{tabular}{|c|c|}
\hline $\begin{array}{c}0 \\
\text { (Normal) }\end{array}$ & $\begin{array}{l}\text { Tidak terlihat maupun teraba } \\
\text { gondok Gondok teraba tetapi tidak } \\
\text { terlihat apabila leher dalam posisi }\end{array}$ \\
\hline 1 & $\begin{array}{l}\text { normal (tiroid tidak terlihat } \\
\text { membesar). }\end{array}$ \\
\hline & Pembesaran di Leher yang jelas \\
\hline 2 & $\begin{array}{l}\text { normal dan pada palpasi memang } \\
\text { membesar (kelenjar tiroid }\end{array}$ \\
\hline & $\begin{array}{l}\text { dianggap membesar apabila besar } \\
\text { tiap lobus lateral lebih dari } \\
\text { volume falangs ibu jari pasien } \\
\text { yang diperiksa. }\end{array}$ \\
\hline
\end{tabular}

\section{HASIL PENELITIAN}

Keadaan Umum Daerah

Kecamatan Kuranji memiliki luas daerah 57,41 $\mathrm{km}^{2}$, terdiri dari 9 kelurahan. Terdapat dua jenis pemukiman, yaitu pemukiman tradisional dan pemukiman baru berupa perumahan - perumahan baru.
Sebelah utara berbatasan dengan Kecamatan Koto Tangah, sebelah selatan dengan Kecamatan Padang Timur dan Kecamatan PadangUtara, sebelah timur dengan Kecamatan Pauh, dan sebelah barat dengan Kecamatan Nanggalo dan Kecamatan Koto Tangah.

Penduduk berjumlah 113.976 jiwa yang terdiri dari 28.160 kepala keluarga. Kepadatan penduduk 1.985 jiwa $/ \mathrm{km}^{2}$ dengan kecepatan laju pertambahan penduduk yang sangat cepat karena banyaknya pemukiman baru.

Fasilitas kesehatan terdiri dari 3 Puskesmas, 6 Puskesmas Pembantu, dan 69 Posyandu. Pada ketiga Puskesmas bertugas 3 orang dokter umum dan 3 orang dokter gigi.

Fasilitas pendidikan di Kecamatan ini cukup, terdiri dari TK, SD, SLTP, SMU, dan Perguruan Tinggi. TK berjumlah 28 buah, SD berjumlah 53 buah dengan jumlah murid 13.650 orang, SLTP sebanyak 7 sekolah, SMU sebanyak 3 sekolah, dan Perguruan Tinggi sebanyak 1 buah.

Madrasah Ibtidaiyah Negeri (MIN) Korong Gadang merupakan salah satu dari 53 SD yang terdapat di Kecamatan Kuranji dengan jumlah murid 220 siswa, serta 20 orang pegawai dan guru. Jumlah murid kelas II, III, IV, V, dan VI sebanyak 189 siswa. Sekolah ini dibangun diatas tanah seluas \pm $1.384 \mathrm{~m}^{2}$, dengan luas bangunan $892 \mathrm{~m}^{2}$, terdiri dari 8 buah ruang kelas, 1 buah ruang kantor, 1 buah pustaka, dan 1 buah UKS.

\section{Karakteristik Responden}

Penelitian dilakukan terhadap 130 murid yang memenuhi kriteria inklusi dan eksklusi dari 189 murid kelas II sampai VI Madrasah Ibtidaiyah Negeri (MIN) Korong Gadang Kecamatan Kuranji Kota Padang. Pada 
setiap kelas didapatkan jumlah responden yang berbeda.

Tabel.1. Karakteristik responden

\begin{tabular}{|l|c|c|}
\hline Karakteristik & n & \% \\
\hline Jenis Kelamin & & \\
Laki-laki & 59 & 45,4 \\
Perempuan & 71 & 54,6 \\
\hline
\end{tabular}

Penelitian ini dilakukan terhadap 59 $(45,4 \%)$ laki-laki dan $71 \quad(54,6 \%)$ perempuan.

\section{Derajat Gondok}

Tabel .2. Distribusi frekuensi derajat gondok

\begin{tabular}{|c|c|c|}
\hline $\begin{array}{c}\text { Derajat } \\
\text { Gondok }\end{array}$ & $\mathbf{n}$ & $\boldsymbol{\%}$ \\
\hline 0 & 49 & 37,7 \\
1 & 72 & 55,4 \\
2 & 9 & 6,9 \\
\hline Total & 130 & 100 \\
\hline
\end{tabular}

Dari 130 responden 72 orang $(55,4 \%)$ diantaranya menderita gondok derajat 1 , dan 9 orang $(6,9 \%)$ menderita gondok derajat 2 .

Tabel .3. Karakteristik responden yang menderita penyakit gondok.

\begin{tabular}{|c|c|c|}
\hline Karakteristik & n & \% \\
\hline Jenis Kelamin & & \\
Laki-laki & 39 & 48,1 \\
Perempuan & 42 & 51,9 \\
\hline
\end{tabular}

Dari 81 responden yang menderita penyakit gondok (grade 1 dan 2) 39 orang $(48,1 \%)$ berjenis kelamin lakilaki dan 42 orang $(51,9 \%)$ berjenis kelamin perempuan.
Hubungan Penyakit Gondok dengan Kadar Yodium dalam Urin

Tabel .4. Distribusi penyakit gondok menurut kadar yodium dalam urin responden

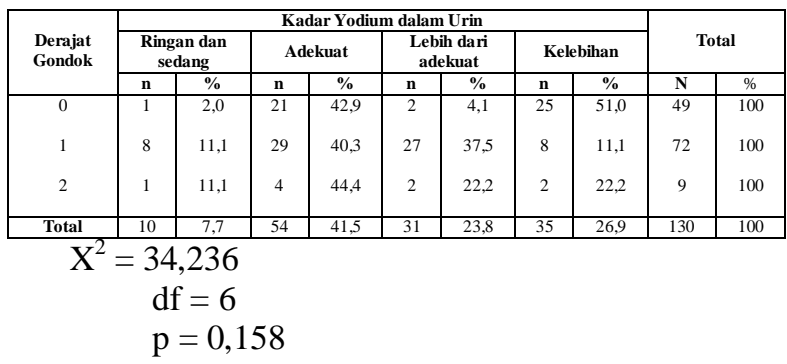

Pada tabel 4 terlihat kecenderungan yang tidka menderita penyakit gondok mempunyai kadar yodium urin yang lebih baik dibandingkan responden yang menderita penyakit gondok, tetapi hal ini tidak bermakna secara statistic dengan $\mathrm{p}>0,05$.

\section{PEMBAHASAN \\ Analisis}

Kuranji merupakan salah satu kecamatan di kota Padang dengan luas daerah $57,41 \mathrm{~km}^{2}$ dan kepadatan penduduk $1.985 \mathrm{jiwa} / \mathrm{km}^{2}$. Terdapat 2 jenis pemukiman, yaitu pemukiman tradisional dan pemukiman baru. Fasilitas kesehatan dan fasilitas pendidikan cukup.

Madrasah Ibtidaiyah Negeri (MIN) Korong Gadang merupakan salah satu dari 53 SD yang terdapat di Kecamatan Kuranji dengan jumlah murid 220 siswa, serta 20 orang pegawai dan guru. Jumlah murid kelas II, III, IV, V, dan VI sebanyak 189 siswa. Sekolah ini dibangun diatas tanah seluas $\pm 1.384 \mathrm{~m}^{2}$ dengan luas bangunan $892 \mathrm{~m}^{2}$. Fasilitas belajar dan kesehatan cukup memadai dengan 8 buah ruang kelas, I buah ruang kantor, 1 buah pustaka, dan 1 buah UKS. 


\section{Karakteristik Sampel}

Penelitian dilakukan terhadap 130 murid yang memenuhi kriteria inklusi dan eksklusi dari 189 murid kelas II sampai VI Madrasah Ibtidaiyah Negeri Korong Gadang Kecamatan Kuranji Kota Padang, 59 laki-laki $(45,4 \%)$ dan 71 perempuan $(54,6 \%)$.

\section{Derajat Gondok}

Pada penelitian ini diteliti 130 murid dan didapatkan 81 murid $(62,30 \%)$ telah mengalami pembesaran kelenjar gondok derajat 1 dan 2. Jadi prevalensi penyakit gondok di Madrasah Ibtidaiyah Negeri (MfN) Korong Gadang Kecamatan Kuranji Kota Padang sebesar 62,3\% (endemik berat). Angka yang didapat lebih tinggi daripada hasil survey pemetaan GAKY Kota Padang untuk Kecamatan Kuranji tahun 2006 , yaitu $32,1 \%$. $^{(10)}$

Pada penelitian ini juga didapatkan, dari 81 responden yang menderita penyakit gondok (grade I dan 2) $48,1 \%$ berjenis kelamin laki-laki dan $51,9 \%$ berjenis kelamin perempuan. Triyono G di Surabaya tahun 2004 melaporkan gondok lebih sering pada anak perempuan dibandingkan laki-laki. Mariko R di Padang tahun 2007 menemukan sebaliknya. ${ }^{(13)}$

\section{Hubungan Penyakit Gondok dengan Kadar Yodium dalam urin}

Penelitian ini menunjukkan tidak ada hubungan yang bermakna antara kadar yodium dalam urin dengan angka kejadian penyakit gondok.

Proses terjadinya kerusakan
otak telah berlangsung lama
(irreversible) pada daerah gondok
endemik terutama dengan TGR yang
tinggi, berbeda dengan daerah gondok
endemik yang baru dikenal. Kota
Padang merupakan daerah gondok

endemik dengan terjadinya peningkatan TGR dalam kurun waktu beberapa tahun, kerusakan otak masih ringan dan belum mempengaruhi tingkat kecerdasan. ${ }^{(13)}$

\section{KESIMPULAN DAN SARAN \\ Kesimpulan}

1. Jumlah murid SD kelas II, III, IV, V, dan VI yang menderita penyakit gondok di Madrasah Ibtidaiyah Negeri (MIN) Korong Gadang Lecamatan Kuranji Kota Padang adalah 81 orang $(62,3 \%)$.

2. Kadar Yodium dalam Urin anak yang menderita penyakit gondok tidak jauh berbeda dengan rnurid yang tidak menderita penyakit gondok.

3. Tidak terdapat hubungan antara penyakit gondok dan kadar yodium dalam urin anak Madrasah Ibtidaiyah Negeri (MIN) Korong Gadang Kecamatan Kuranji Kota Padang.

\section{Saran}

1. Mengingat tingginya prevalensi gondok endemik pada anak-anak, perlu dicari penyebab tingginya TGR di Kota Padang.

2. Pemberian kapsul yodium yang diprioritaskan pada anak usia sekolah didaerah endemik GAKY.

3. Perlu dilakukan penyuluhan pada masyarakat untuk meningkatkan kesadaran penggunaan garam beryodium dengan kadar sesuai standar kesehatan (>30 ppm).

\section{KEPUSTAKAAN}

1. Jalal F, 2000. Peran Kesehatan \&. Gizi Dalam Upaya Peningkatan Kualitas Sumber 
Daya Manusia, Jakarta: ICPI (lnsan Cita Pendidikan Indonesia), hlm 1-20.

2. Departemen Kesehatan RI, 2005. Pedoman Perbaikan Gizi Anak Sekolah Dasar dan Madrasah Ibtidaiyah, Iakarta, hlm 3-5.

3. Direktorat Gizi Masyarakat, Direktorat Jendral Bina Kesehatan Masyarakat, Departemen Kesehatan, 2003. Program Penanggulangan Anemia Gizi Pada Wanita Usia Subur, Jakarta, hlm 1.

4. Suara Merdeka, 2007. Gangguan Akibat Kekurangan Yodium, Penyakit Penyebab Retardasi Mental. Warta Terkini GAKY. Diakses dari http/l tanggal 2 Maret 2007.

5. Utiger RD, 2006. Iodine Nutrition - More is Better. The New England Journal of Medicine. Diakses dari http:/lcontent.ne-im.org, tanggal 30 Januari 2008.

6. Mutalazirrah, Pengembangan 2005. Informasi Sistem Pemantauan.

7. Fadil O, 2000. Pengaruh GAKY Terhadap Sumber Daya Manusia (SDM), Padang: Fakultas Kedokteran Universitas Andalas. hlm 1-7.
8. Sihadi, 2000. Anak Gizi Buruk, Tnggung Jawab Siapa?. Media Litbang Kesehatan Volume X Nomor 1: 54-6.

9. DjokomoeljantoR, 2006. Gangguan Akibat Kurang Yodium. Dalam Buku Ajar Ilmu Penyakit Dalam Jilid III Edisi IV, Jakarta: Pusat Penerbitan Departemen Ilmu Penyakit Dalam Fakultas Kedokteran Universitas Indonesia, hlm 1966-70.

10. Granner DK, 2003. Hormon Tiroid. Dalam Biokimia Harper Edisi 25, jakarta: EGC, hlm 533-8.

11. Banindari Rachmawati, 2006 Jurnal GAKY Indonesia, 2006. Pemeriksaan Kadar Yodium dalam Urin. Diakses dari http:/www.idd-indonesia.net April 2006.

12. Djoko Kartono dkk, 2007 Jurnal GAKY Indonesia, 2007. Ekskresi Yodium Urin Anak Sekolah Survei Evaluasi Gangguan akibat Kekurangan Yodium di Indonesia tahun 2003. Diakses dari http://www.idd-lndonesia.net. April 2007.

13. Mariko 2007. Pemeriksaan Iodium Urine pada Masyarakat Daerah Pantai. Laporan Penelitian dan Ilmiah RSUP Dr. M. Djamil Padang. 